\title{
The effects of human land use on flow regime and water chemistry of headwater streams in the highlands of Chiapas
}

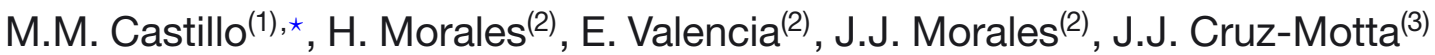

Received October 2, 2012

Revised January 11, 2013

Accepted January 12, 2013

Key-words: stream, catchment, land use, nutrient enrichment, abstraction

\section{ABSTRACT}

We studied the effects of land use changes on flow regime and water chemistry of headwater streams in the highlands of Chiapas, a region in southern Mexico that has experienced high rates of deforestation in the last decades. Samples for water chemistry were collected and discharge was measured between September 2007 and August 2008 at eight streams that differed in the land uses of their riparian and catchment areas, including streams draining protected forested areas. Streams with high forest cover $(>70 \%)$ in their catchments maintained flow through the year. Streams draining more disturbed catchments exhibited reduced or no flow for 4-6 months during the dry season. Nitrate concentrations were lower at streams draining forested catchments while highest concentrations were measured where conventional agriculture covered a high proportion of the catchment and riparian zone. Highest phosphorus concentrations occurred at the catchment where poultry manure was applied as fertilizer. Differences between forest streams and those draining disturbed areas were correlated with the proportion of forest and agriculture in the riparian zone. Variation in stream variables among sampling dates was lower at the forest sites than at the more disturbed study streams. Conversion of forest into agriculture and urban areas is affecting flow regime and increasing nutrient concentrations, although the magnitude of the impacts are influenced by the type of agricultural practices and the alteration of the riparian zone.

\section{RÉSUMÉ}

Les effets de l'utilisation des terres sur le régime d'écoulement et la composition chimique de l'eau des ruisseaux de tête de bassin des plateaux du Chiapas

Mots-clés : ruisseau, bassin versant, aménagement du territoire,
Nous avons étudié l'influence des changements d'aménagement du territoire sur le régime hydrographique et la composition hydrochimique de ruisseaux des plateaux du Chiapas, une région au sud du Mexique qui a subi une déforestation de grande ampleur ces dernières décennies. Entre septembre 2007 et août 2008, nous avons prélevé des échantillons d'eau et avons mesuré l'écoulement au niveau de 8 ruisseaux, qui différaient par l'utilisation des terres de leurs bassins

(1) El Colegio de la Frontera Sur, Villahermosa, Tabasco, CP 86280, Mexico

(2) El Colegio de la Frontera Sur, San Cristóbal de Las Casas, Chiapas, CP 29290, Mexico

(3) Departamento de Estudios Ambientales, Universidad Simón Bolívar, Apartado 89000 Baruta, Caracas 1080, Venezuela

* Corresponding author: mmcastillo@ecosur.mx 
eutrophisation, captage d'eau versants et de leurs zones riveraines; ceci incluait des ruisseaux drainant des zones forestières protégées. Les ruisseaux avec une couverture forestière importante dans leurs bassins versants ( $>70 \%$ ) étaient en eau toute l'année. Les cours d'eau drainant des bassins versants plus antropisés montraient une réduction ou non du flux durant 4 à 6 mois lors de la saison sèche. Les concentrations en nitrates étaient plus basses dans les ruisseaux drainant des bassins versants forestiers tandis que les plus hautes concentrations furent mesurées lorsque l'agriculture conventionnelle occupait une partie importante des bassins versants et des zones riveraines. La conversion de forêts en zones agricoles et urbaines affecte les régimes hydrographiques et augmente les concentrations en substance nutritive; en outre, l'impact varie selon le type d'agriculture pratiquée et le degré d'altération des zones riveraines.

\section{INTRODUCTION}

Headwaters influence flow conditions, water quality and ecological functioning of downstream aquatic ecosystems (Binckley et al., 2010). Streams draining these areas exhibit high biogeochemical processing because the great interaction between terrestrial and aquatic systems and the enhanced transformation and retention of nutrients and organic matter due to the large surface to volume ratio in their small channels (Polis et al., 1997; Peterson et al., 2001; Gomi et al., 2002; Lowe and Likens, 2005). Headwater streams influence water and material transport by large rivers because they represent between $60-80 \%$ of the cumulative length of river and drain a similar proportion of the catchment (Benda et al., 2005; Wipfli et al., 2007). In addition, the upper part of the catchments exhibits a great variety of abiotic and biotic conditions, which is associated with high habitat and taxa diversity (Meyer et al., 2007). Despite their ecological role, headwater streams are highly vulnerable to human disturbance probably because their abundance and small size (Meyer and Wallace, 2001). Channelization, water diversion and changes in catchment and riparian land use are among the threats to the hydrology, water quality and biodiversity in fluvial networks (Meyer et al., 2007). Conversion of forest to agriculture and urban lands increases channelization, filling and piping of small streams, which is accompanied by habitat alteration and increased flood risk (Meyer and Wallace, 2001; Winter, 2007; Elmore and Kaushal, 2008). Deforestation can also alter stream metabolism and the processing of organic matter in headwater streams, affecting the food supply for aquatic organisms (Clapcott and Barmutta, 2010). Changes in land use in the headwaters can increase nitrogen ad phosphorus loading and reduce nutrient retention, which can result in changes in stream metabolism and the eutrophication and hypoxia of distant downstream ecosystems (Alexander et al., 2007; Freeman et al., 2007). Thus, alteration of headwaters can affect the ecological integrity of freshwater and coastal ecosystems.

Tropical mountain headwaters have been affected by high deforestation rates in the last decades (Mulligan, 2010; Ponnette-González et al., 2010). Tropical montane forests, which generally occupy steep headwater areas, have experienced higher conversion rates $(1.1 \%)$ than tropical lowland forests (0.8\%) (Mulligan et al., 2010; Scatena et al., 2010; Toledo-Aceves et al., 2011). In particular, loss of Tropical montane cloud forests (TMCF) is estimated in 55\% of the original worldwide cover (Mulligan, 2010). TMCF represent the habitat of many species and exhibit a high degree of endemism (Vargas-Rodríguez et al., 2010; Toledo-Aceves et al., 2011; Ledo et al., 2012). In addition, TMCF provide services to society such as provision of water and protection against erosion (Bruijnzeel, 2004; Martínez et al., 2009; Mulligan, 2010). Conversion of TMCF into other land uses, such as agriculture and pastureland, selectivelogging, and climate change are among the major threats to TMCF and can have a negative impact on biodiversity and the supply of water for human consumption and freshwater ecosystems (Cayuela et al., 2006a,b; Scatena et al., 2010; Ponce-Reyes et al., 2012). 
In Mexico, a high proportion (50-68\%) of TMCF areas has been lost and estimates suggest that the country exhibits the greatest deforested area of cloud forest worldwide (Mulligan, 2010; Toledo-Aceves et al., 2011). For example, in the highlands of Chiapas, in Southern Mexico, conversion into agriculture and pastureland reduced forest cover in $50 \%$ percent between 1975 and 2000, while TMCF was the type of forest that experienced the greater decrease from 19.7\% in 1975 to 2.5\% in 2000 (Cayuela et al., 2006b; González-Espinosa et al., 2009). Although several studies have addressed the causes of deforestation in the highlands of Chiapas (Ochoa-Gaona and González-Espinosa, 2000; Ochoa-Gaona, 2001; Cayuela et al., 2006b; Figueroa-Jáuregui et al., 2011), little is known about the ecology of headwater streams in the region and how land use changes are impacting these ecosystems.

The objective of this study was to evaluate how conversion of forest to agriculture and urban land is related to flow regime and water quality of headwater streams draining the Huitepec Mountain in the highlands of Chiapas. To achieve this objective, we measured discharge and several water quality variables at headwater streams that differ in the land use of their catchments and riparian zones, including streams draining protected forested areas. The results of this study provide information on the conditions of headwater streams draining minimally disturbed catchments and the effects of conversion into different agricultural practices and urban lands.

\section{MATERIALS AND METHODS}

\section{> STUDY AREA}

This study was conducted in the highlands of Chiapas, a region located in Southern México, above 1500 m of elevation. In addition to cloud forest, the region also exhibits oak, pine-oak and pine forests. Despite the high deforestation experienced in the region, some areas in these highlands still exhibit forest patches in a high quality matrix composed of traditional agriculture and secondary vegetation resulting in a diverse landscape which can maintain habitat diversity (Cayuela et al., 2006b). Traditional agriculture in the area consists on polycrops or agroforestry systems of vegetables and corn with none or little agrochemical inputs. However, many landscapes in Chiapas are now surrounded by a matrix with extensive pasture land (Sánchez et al., 2000), as well as vegetable growth in monocrops with high pesticides and fertilizer inputs (Morales et al., 2003) which can threat biodiversity and increase loading of nutrient and pollutants to streams. In addition, Chiapas' highlands are characterized by high precipitation and steep terrains (Cayuela et al., 2006a) so removal of forest can also facilitate erosion, landslides and transport of water and sediments to the lowlands, increasing the risk of floods (Caballero et al., 2006).

The Huitepec Mountain is located west of San Cristóbal de Las Casas, in the central part of the Highlands of Chiapas. Huitepec is an inactive volcano, formed during the early Pleistocene (850.000 bp) (Albarrán et al., 2003). The mountain exhibited an altitude range between 2200 and 2720 masl (Wilson and Will, 1997). Climate is temperate with annual mean temperature between 12 and $18{ }^{\circ} \mathrm{C}$ and annual precipitation is $1300 \mathrm{~mm}$ (Ramírez-Marcial et al., 1998; Arriaga et al., 2000). Soils are chromic luvisols and lithic leptosols (Arriaga et al., 2000 ) and the mountain exhibits areas covered by oak, oak-pine and tropical montane cloud forests (Ramírez-Marcial et al., 1998). Two forest protected areas are located on the Huitepec: 1) The private-owned Huitepec Ecological Reserve, located on the eastern part of the mountain, was created in 1987 and has an area of 136 ha; 2) The natural protected area Huitepec-Los Alcanfores is a state reserve with an extension of 102.8 ha, located next to the Huitepec Ecological Reserve and created in 2007. The Huitepec Mountain is included in the Huitepec-Tzontehuitz Priority Conservation Area, defined by the Mexican National Commission for the Use and Knowledge of Biodiversity (CONABIO) based on the high endemism, presence of endangered species, and its importance as a major source of water for local communities. Near $80 \%$ of the water supplied to San Cristóbal de Las Casas, San Juan Chamula and Tenejapa is provided by the Huitepec-Tzontehuitz massif (Arriaga et al., 2000). Despite its 
importance as biodiversity and water reservoirs, land use changes are threatening the Huitepec landscape. Traditional agriculture, pasture and forest patches conserved by producers outside the forest reserves have been replaced by urban areas and intensive agriculture that uses pesticides and synthetic fertilizers (Morales et al., in press).

\section{$>$ LAND USE ANALYSES}

Land use for the study catchments was classified from a 2006 Quick Bird image (3 bands, pixel size $0.6 \mathrm{~m}$ ). Polygons for land use classification were defined on the screen using a 1:2000 scale. The following land use categories were employed: forest, pasture, secondary vegetation, agriculture, urban land, industrial, greenhouses and roads. Field visits helped to confirm land use classification based on the image. Streams and catchment areas were delineated from an elevation model. By using a GIS, land use was determined for the catchment area upstream from each sampling site. Land use for riparian areas was estimated for 5 and $50 \mathrm{~m}$ buffer strips on each side of stream network upstream of a site. The selection of these buffer widths was based on the width of the riparian area established in the Mexican National Water Legislation $(5 \mathrm{~m})$ and on values reported to effectively reduce nutrient inputs $(>50 \mathrm{~m})$ (Mayer et al., 2005). Riparian buffers were overlaid with the land use layer to obtain the land use within the riparian zone. For each catchment, type of agriculture, crops and fertilizers were obtained from field visits and interviews with the producers.

\section{> STREAM SAMPLING}

Eight headwater streams draining the Huitepec Mountain were sampled between September 2007 and August 2008 at three to four-week intervals. The study catchments encompassed a high diversity of land use types. Three sites were located on streams draining catchments where forest represented the dominant land use. Forest 1 stream runs through the natural protected area Huitepec-Los Alcanfores, while streams Forest 2 and 3 drain the Huitepec Ecological Reserve (Figure 1). However, the northern part of Forest 3 catchment is located outside the reserve and it is covered primarily by secondary vegetation. Other study catchments showed a mixture of forest, cropland, pasture and urban land (Table I). All study streams, except San Nicolás, drain into the valley of San Cristóbal de Las Casas (Valley of Jovel), an endorreic watershed, where a large proportion of water courses are polluted from discharge of urban wastewater (Velázquez-Velázquez and Schmitter-Soto, 2004). San Nicolás is located in the Zinacantán river basin, a tributary of the Hondo river, which drains into the Chicoasen hydroelectric dam.

At each sampling site, discharge was estimated from measurements of depth and current velocity (stream flowmeter, MPPS1, Geopack, UK) at three cross-channel transects. Specific conductance and water temperature were measured with an Extech EC400 meter. Water samples were collected at each site and transported to the laboratory. $\mathrm{pH}$ was measured with an Orion 230A pHmeter and alkalinity determined by potentiometric titration (APHA, 1995). Nitrate- $\mathrm{N}$ concentrations were determined by the cadmium reduction method, nitrite$\mathrm{N}$ by diazotization and organic $\mathrm{N}$ by Kjeldahl (APHA,1995). Ammonium-N was determined by the salicylate method (Reardon et al., 1966). Total phosphorus was analyzed by digestion with persulphate to soluble reactive phosphorus, which was determined by the ascorbic acid method (APHA, 1995).

\section{> DATA ANALYSIS}

The wet season stream data was selected to make the comparisons among the study streams because half of the sampling sites did not exhibit flow during the dry season. Wet season included sampling dates from September 2007 through November 2007 and from June 2008 

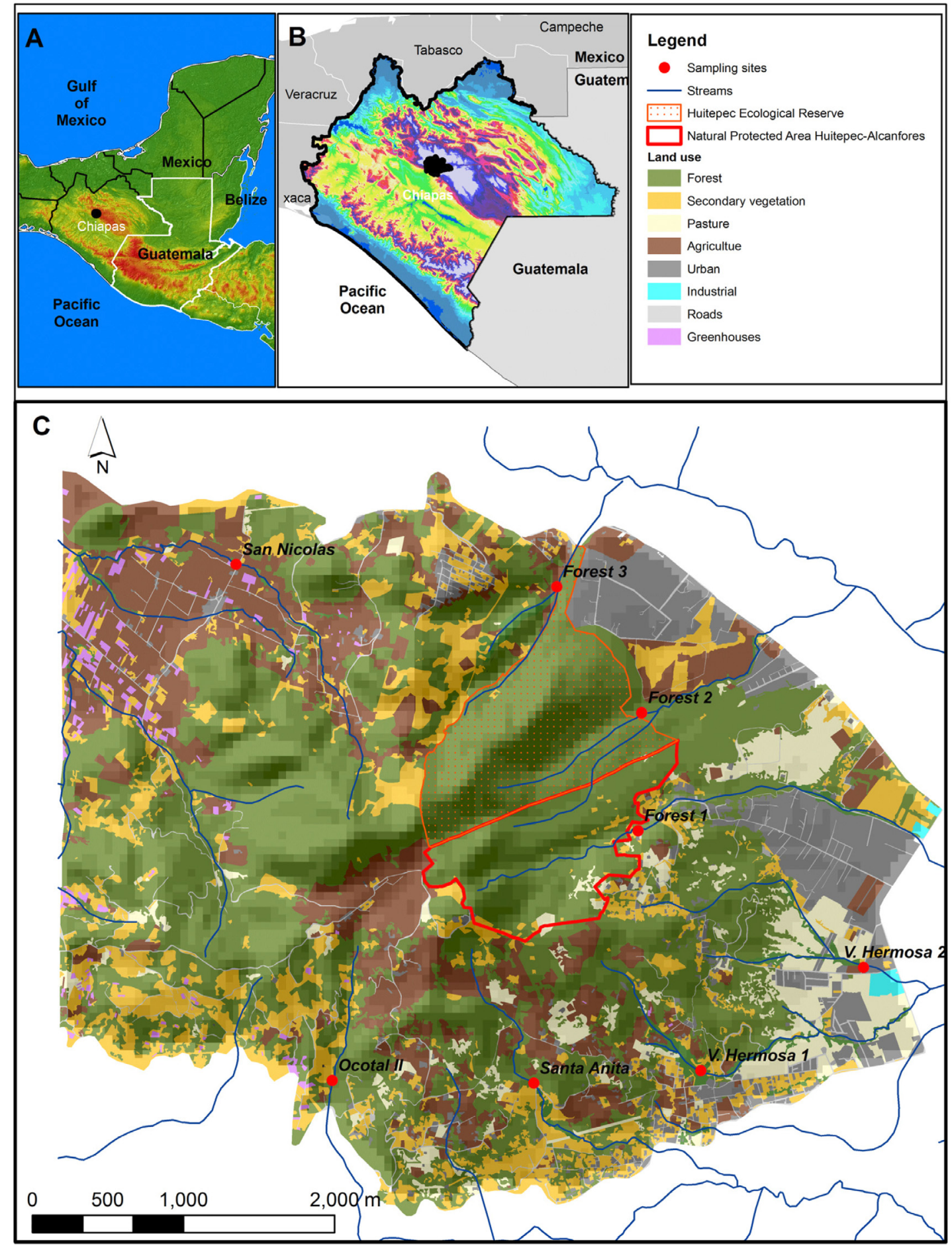

\section{Figure 1}

Location of sampling sites at the Huitepec Mountain, Chiapas, Mexico. A) Relative location of Chiapas in southern Mexico. B) Location of the study area (in black) in the state of Chiapas. C) Sampling sites at the Huitepec Mountain. The Huitepec Ecological Reserve and the Natural Protected Area Huitepec-Los Alcanfores are also shown (see legend). 
Table I

Land use (\%) at the catchment above each sampling site.

\begin{tabular}{|l|c|c|c|c|c|c|c|}
\cline { 2 - 8 } \multicolumn{1}{c|}{} & $\begin{array}{c}\text { Stream } \\
\text { order }\end{array}$ & $\begin{array}{c}\text { Gatchment area } \\
(\mathrm{ha})\end{array}$ & $\begin{array}{c}\text { Forest } \\
(\%)\end{array}$ & $\begin{array}{c}\text { Secondary } \\
\text { Vegetation } \\
(\%)\end{array}$ & $\begin{array}{c}\text { Pasture } \\
(\%)\end{array}$ & $\begin{array}{c}\text { Agriculture } \\
(\%)\end{array}$ & $\begin{array}{c}\text { Urban } \\
(\%)\end{array}$ \\
\hline Forest 1 & 1 & 71.1 & 86.8 & 7.3 & 4.4 & 0.4 & 0.9 \\
\hline Forest 2 & 1 & 50.2 & 99.9 & 0.0 & 0.1 & 0.0 & 0.0 \\
\hline Forest 3 & 2 & 113.7 & 69.5 & 21.8 & 0.1 & 7.7 & 0.7 \\
\hline Ocotal II & 1 & 115.4 & 53.0 & 13.1 & 0.9 & 42.5 & 1.1 \\
\hline Santa Anita & 1 & 43.9 & 55.7 & 9.4 & 4.7 & 31.6 & 0.5 \\
\hline Vista Hermosa 1 & 2 & 55.8 & 60.4 & 5.8 & 7.2 & 28.6 & 1.7 \\
\hline Vista Hermosa 2 & 2 & 139.6 & 53.3 & 11.6 & 18.4 & 2.0 & 11.4 \\
\hline San Nicolás & 1 & 119.8 & 50.6 & 11.0 & 0.0 & 34.7 & 1.1 \\
\hline
\end{tabular}

\section{Table II}

Description of agriculture at the study catchments.

\begin{tabular}{|l|c|c|c|}
\hline Site & Agricultural practice & Crops & Fertilizers \\
\hline Forest 1 & - & - & - \\
\hline Forest 2 & - & - & - \\
\hline Forest 3 & $\begin{array}{c}\text { Subsistence annual } \\
\text { monocrops }\end{array}$ & Vegetables, corn & Synthetic and organic \\
\hline Ocotal II & $\begin{array}{c}\text { Intensive annual } \\
\text { monocrops }\end{array}$ & Vegetables, flowers & Synthetic and organic \\
\hline Santa Anita & $\begin{array}{c}\text { Organic, agroforestry } \\
\text { systems }\end{array}$ & Vegetables & $\begin{array}{c}\text { Synthetic and organic } \\
\text { (compost) }\end{array}$ \\
\hline Vista Hermosa 1 & $\begin{array}{c}\text { Intensive organic, } \\
\text { agroforestry systems }\end{array}$ & Vegetables & Poultry manure \\
\hline Vista Hermosa 2 & $\begin{array}{c}\text { Intensive annual } \\
\text { monocrops }\end{array}$ & Vegetables & Synthetic \\
\hline San Nicolás & $\begin{array}{c}\text { Intensive, } \\
\text { monocrops }\end{array}$ & Vegetables, flowers & Synthetic \\
\hline
\end{tabular}

through August 2008, totaling 13 sampling dates. A draftsman plot analysis was conducted to identify redundant variables based on Pearson's correlations and to detect skewness in the distribution of the variables. Variables that exhibited correlations higher than 0.9 were removed as indicated by Clarke and Ainsworth (1993). Principal Component Analysis (PCA) was performed on stream variables to examine the spatial multivariate pattern across sampling sites and along sampling times. Indexes of multivariate dispersion were calculated to estimate variation along sampling times for each stream. A Canonical Analysis of Principal Coordinates (CAP) (Anderson and Willis, 2003) was done to correlate response variables (stream variables) with predictive variables (land use variables and catchment area). To conduct this analysis, centroids among sampling times were calculated for each site using the matrix for stream data. This resemblance matrix was ordinated using the information of the land use matrix as constraining information. The above multivariate analyses were conducted using PRIMER v 6.0 software (Plymouth Marine Laboratory, UK).

\section{RESULTS}

Forest cover dominated the catchments of Forest 1, 2, and 3 streams. The proportion of cropland was higher at sites Ocotal II, Santa Anita, Vista Hermosa 1 and San Nicolas (Table I). Horticulture was the main type of agriculture at Santa Anita, Vista Hermosa 1, and San Nicolás while flower cultivation was observed at Ocotal II and San Nicolás (Tables I and II). Greenhouses were observed at Ocotal II $(0.25 \%$ of catchment area), Vista Hermosa $1(0.28 \%)$ and San Nicolás (0.92\%). Intensive monocrops occurred at Ocotal II, Vista Hermosa 2 and San Nicolás, while at Santa Anita and Vista Hermosa 1, organic agriculture and agroforestry dominated. Greater proportion of urban areas occurred at Vista Hermosa 2. Riparian vegetation 


\section{Table III}

Land use in riparian areas upstream from each sampling site based on 5 and $50 \mathrm{~m}$ buffer strips.

\begin{tabular}{|l|c|c|c|c|c|c|c|c|c|c|}
\cline { 2 - 12 } \multicolumn{1}{c|}{} & \multicolumn{2}{c|}{$\begin{array}{c}\text { Forest } \\
(\%)\end{array}$} & $\begin{array}{c}\text { Secondary } \\
\text { Vegetation } \\
(\%)\end{array}$ & \multicolumn{2}{c|}{$\begin{array}{c}\text { Pasture } \\
(\%)\end{array}$} & \multicolumn{2}{c|}{$\begin{array}{c}\text { Agriculture } \\
(\%)\end{array}$} & $\begin{array}{c}\text { Urban } \\
(\%)\end{array}$ \\
\hline $\begin{array}{l}\text { Width of buffer } \\
\text { strip (m) }\end{array}$ & $\mathbf{5}$ & $\mathbf{5 0}$ & $\mathbf{5}$ & $\mathbf{5 0}$ & $\mathbf{5}$ & $\mathbf{5 0}$ & $\mathbf{5}$ & $\mathbf{5 0}$ & $\mathbf{5}$ & $\mathbf{5 0}$ \\
\hline Forest 1 & 96.5 & 95.9 & 3.5 & 3.8 & 0.0 & 0.1 & 0.0 & 0.0 & 0.0 & 0.2 \\
\hline Forest 2 & 100.0 & 100.0 & 0.0 & 0.0 & 0.0 & 0.0 & 0.0 & 0.0 & 0.0 & 0.0 \\
\hline Forest 3 & 87.7 & 82.5 & 3.5 & 8.0 & 0.0 & 0.0 & 8.9 & 9.5 & 0.0 & 0.0 \\
\hline Ocotal II & 66.0 & 57.9 & 27.9 & 28.2 & 0.0 & 0.0 & 6.2 & 14.1 & 0.0 & 0.0 \\
\hline Santa Anita & 77.9 & 60.9 & 4.7 & 5.8 & 0.0 & 2.4 & 15.9 & 30.2 & 0.0 & 0.0 \\
\hline Vista Hermosa 1 & 76.0 & 51.4 & 6.6 & 8.1 & 7.7 & 15.9 & 9.7 & 21.8 & 0.1 & 2.1 \\
\hline Vista Hermosa 2 & 77.2 & 56.5 & 13.1 & 13.4 & 5.8 & 19.5 & 0.0 & 0.8 & 2.4 & 7.3 \\
\hline San Nicolás & 37.3 & 23.5 & 19.1 & 12.8 & 0.0 & 0.0 & 40.7 & 59.2 & 1.5 & 1.0 \\
\hline
\end{tabular}

\section{Table IV}

Average (standard deviation) and coefficient of variation for discharge values measured during the study period. Days with no flow accounts for the number of days that the streams did not exhibit flow. Water abstraction refers to the presence of weirs and pipes for water withdrawal from the stream channel.

\begin{tabular}{|l|c|c|c|c|}
\hline Site & $\begin{array}{c}\text { Discharge } \\
\left({\mathrm{L} \cdot \mathrm{S}^{-1}}^{-1}\right.\end{array}$ & $\mathrm{CV}(\%)$ & $\begin{array}{c}\text { Days with } \\
\text { no flow }\end{array}$ & $\begin{array}{c}\text { Water } \\
\text { abstraction }\end{array}$ \\
\hline Forest 1 & $2.7(3.0)$ & 107.9 & 0 & yes \\
\hline Forest 2 & $2.8(0.8)$ & 27.0 & 0 & no \\
\hline Forest 3 & $2.1(2.4)$ & 112.7 & 0 & yes \\
\hline Ocotal II & $12.7(14.0)$ & 111.0 & 0 & yes \\
\hline Santa Anita & $6.0(7.9)$ & 131.6 & 150 & yes \\
\hline Vista Hermosa 1 & $2.1(2.9)$ & 138.9 & 150 & yes \\
\hline Vista Hermosa 2 & $4.8(7.4)$ & 155.7 & 180 & yes \\
\hline San Nicolás & $6.2(6.0)$ & 95.8 & 120 & yes \\
\hline
\end{tabular}

at the 5 and 50 m-buffer strips showed higher forest cover at Forest 1, 2, and 3 than at the other sites (Table III). At the $5 \mathrm{~m}$-buffer strip, the rest of the sites showed forest cover between 37 (San Nicolas) and 78\% (Santa Anita). At the $50 \mathrm{~m}$ buffer, these proportions declined to 23 (San Nicolas) and 60\% (Santa Anita). Riparian forest was replaced primarily by cropland, which showed the greatest proportion at San Nicolás riparian zone (5 m, 40.7\%; $50 \mathrm{~m}$, $59.2 \%)$.

Average annual discharge ranged between 2.1 (Vista Hermosa 1 and Forest 3) and $12.7 \mathrm{~L} \cdot \mathrm{s}^{-1}$ (Ocotal II) (Table IV). Discharge showed a strong seasonal variation in the study streams, with higher discharge between September and November 2007 and between June and August 2008 (Figure 2). During the dry season (December through May), discharge decreased markedly at all study sites and only streams Ocotal II, Forest 1, 2 and 3 flowed during this period. The stream at Forest 2 had the lowest coefficient of variation, while higher values were observed at the intermittent streams. Water abstraction upstream from the sampling sites was observed at all sites except at Forest 2, which is located within the Huitepec Ecological Reserve (Figure 1, Table IV). Extraction was performed by the construction of weirs on the stream channel, from where water was diverted through pipes. In the upper part of some catchments (Vista Hermosa I and II), water storage tanks were observed downslope from seepage areas. $\mathrm{pH}$ ranged between 7.50 and 8.65 and alkalinity between 45 and $335 \mathrm{mg} \mathrm{CaCO}_{3} / \mathrm{L}$ (Table V). Specific conductance and total dissolved solids (TDS) ranged between 105 and $577 \mu \mathrm{S} \cdot \mathrm{cm}^{-1}$ and between 59 and $312 \mathrm{mg} \cdot \mathrm{L}^{-1}$, respectively. Highest conductance, TDS and alkalinity were recorded at Vista Hermosa 1 and lowest at Forest 3 and San Nicolás.

Nitrite and ammonium concentrations were below $0.040 \mathrm{mg} \cdot \mathrm{L}^{-1}$ and $0.090 \mathrm{mg} \cdot \mathrm{L}^{-1}$ respectively (Table V). Most inorganic nitrogen was found in the form of nitrate. Nitrate concentrations ranged from 0.100 to $7.2 \mathrm{mg} \cdot \mathrm{L}^{-1}$. Lower values were measured at Forest 1,2 , and 3 while concentrations at San Nicolás, where agriculture represented more than a third of the catchment area, were higher than at the rest of the sites. At streams that maintained flow 


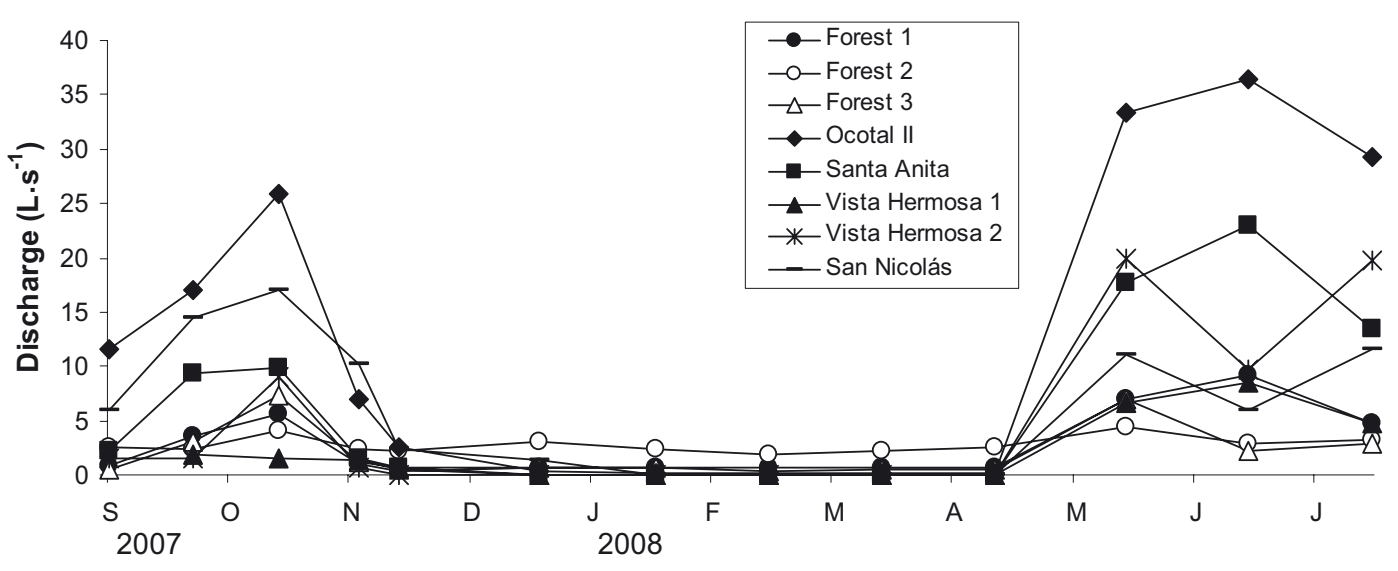

Figure 2

Seasonal variation in discharge at the study streams.

during the entire year, higher nitrate concentrations were observed during the wet season, decreasing markedly during the dry period (Figure 3, Table V). Ocotal II showed greater seasonal variation in concentrations than the forest sites. At the end of the rainy season in 2007, San Nicolás and Ocotal II showed higher concentrations than the forest sites. An increase in nitrate concentration occurred at the beginning of the rainy season in 2008 at the most disturbed sites. Organic nitrogen concentrations ranged between 0.6 and $2.8 \mathrm{mg} \cdot \mathrm{L}^{-1}$. Lower values of total $\mathrm{N}$ were observed at the forest sites while concentrations at San Nicolás were higher than at the other streams. At the forest sites, nitrate represented between $26-28 \%$ of total $\mathrm{N}$ while at San Nicolás this proportion averaged $72 \%$.

SRP ranged between 0.040 and $2.15 \mathrm{mg} \cdot \mathrm{L}^{-1}$ while total $\mathrm{P}$ concentrations were between 0.17 and $2.38 \mathrm{mg} \cdot \mathrm{L}^{-1}$. Highest concentrations were measured at Vista Hermosa 1 (Table V). SRP represented on averaged $51 \%$ of total $P$ at Forest 2 while greater percents were obtained for San Nicolás (73\%) and Vista Hermosa 1 (83\%). Atomic NP ratios were highest at San Nicolás while Vista Hermosa 1 showed the lowest values.

Differences among streams were depicted in the PCA. The forest sites appeared in the upper central part of the graph indicating their lower nutrient levels and permanent flow. Vista Hermosa 1, that exhibited high phosphorus concentrations, percent of SRP, and specific conductance, was located on the bottom right while San Nicolás was placed on the bottom left indicating high nitrate concentrations, percent of nitrate, and NP ratio. Sites with higher $\mathrm{pH}$ and conductivity like Santa Anita and Vista Hermosa 2 were depicted at the right. The placement on Ocotal II at the left indicated higher nitrate concentrations relative to the forest sites, in addition to the presence of flow during the entire study period. Differences among streams located at the forest sites and at more disturbed areas (Vista Hermosa 1 and 2, Ocotal II, San Nicolás and Santa Anita) not only obeyed to their relative position in the multivariate space, but also to their relative dispersion (Table VI). Dispersion of values for stream variables along sampling times for the forest sites were much lower than for the rest of the sites, indicating that conditions at streams draining forested catchments were more homogeneous through the wet season than at streams located at more disturbed catchments.

CAP analyses showed similar patterns of differences for the centroids of streams based on sampling times (Figure 5), indicating clear differences between the forest sites and streams located at more disturbed catchments. These differences were highly correlated with the percentage of forest $(71 \%)$ and agriculture $(42 \%)$ in the $50 \mathrm{~m}$ buffer strip. Dispersion among streams with disturbed catchments was higher than at the forest sites and was correlated with pasture land (59\%) in the $50 \mathrm{~m}$ buffer strip and catchment area (46\%). 


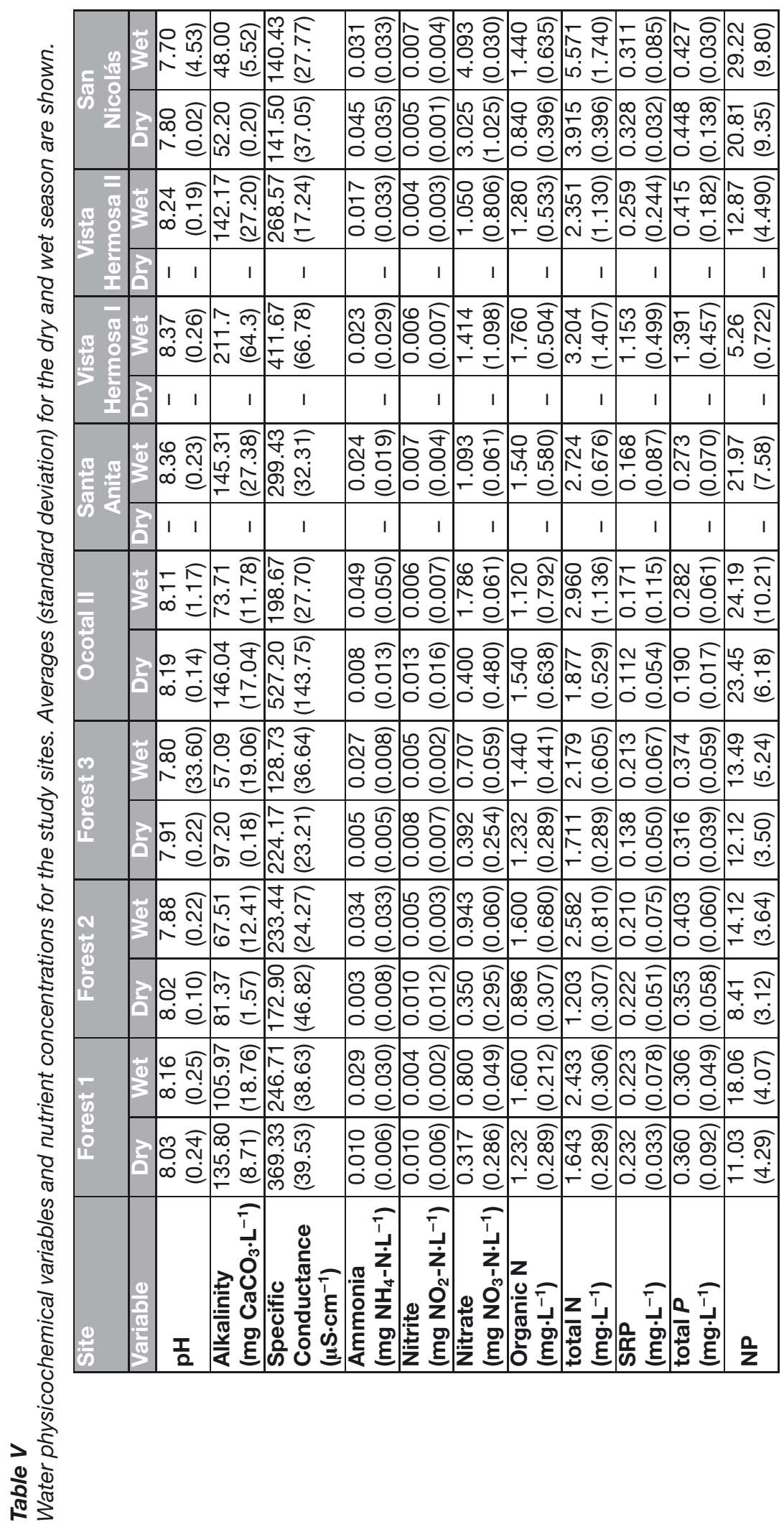




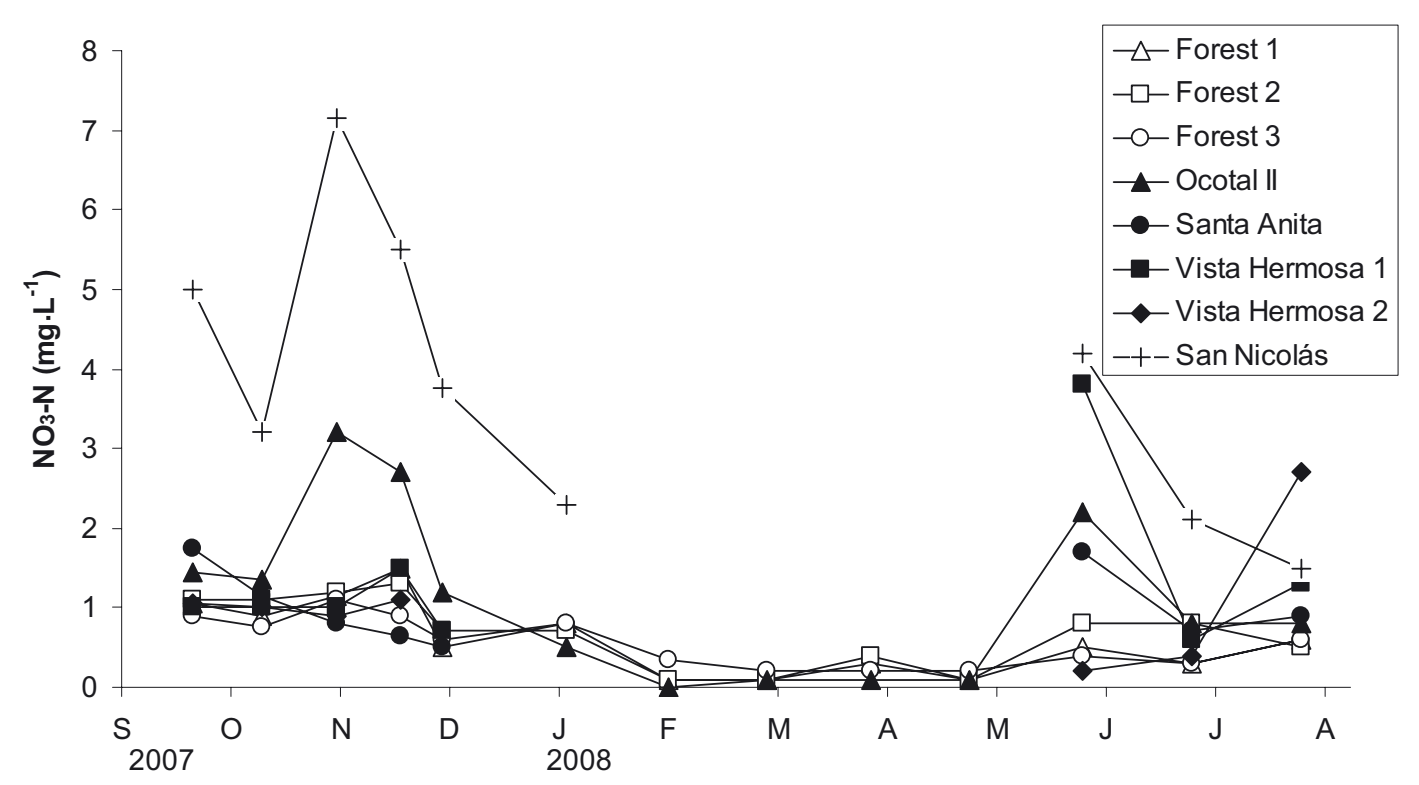

Figure 3

Seasonal variation in nitrate $\left(\mathrm{NO}_{3}-\mathrm{N}\right)$ concentration at the study sites.

Table VI

Indexes of multivariate dispersion among sampling times for each sampling site.

\begin{tabular}{|l|c|}
\hline Site & Dispersion \\
\hline Forest 1 & 0.810 \\
\hline Forest 2 & 0.571 \\
\hline Forest 3 & 0.614 \\
\hline Ocotal II & 1.289 \\
\hline Vista Hermosa 1 & 1.053 \\
\hline Vista Hermosa 2 & 1.061 \\
\hline Santa Anita & 1.412 \\
\hline San Nicolás & 1.190 \\
\hline
\end{tabular}

\section{DISCUSSION}

Land use changes at the Huitepec Mountain are affecting the flow regime and water quality of headwater streams. Although most of the catchments still have a high proportion of forest, conversion to conventional agriculture and urban areas are likely producing changes in the seasonal distribution of discharge and nutrient concentrations, which are evident at the most disturbed streams. Huitepec streams draining catchments located in the forested protected areas maintained flow through the year, despite that two of them (Forest 1 and 3 ) were subject to water abstraction (Table IV). The rest of the streams were dry for a period of 4-6 months. It is not clear whether this intermittency correspond to the natural flow regime of the study streams or it is caused by land use changes because there are not historical flow records for the study area. Hydrological variability among headwater catchments can be high due to spatial variation in geology, soil depth, topography, and vegetation, and this variation decreases as drainage area reaches $1 \mathrm{~km}^{2}$ (Woods et al., 1995; Siddle et al., 2000; Gomi et al., 2002; Bruijnzeel, 2004), which is greater than the area of half of our study catchments (Table I). This natural variation among small catchments could explain, in part, differences in flow regime among the study streams. However, two lines of evidence support the view that flow intermittency can be related to catchment alteration. First, the three study streams with greatest forest cover (>69.5\%) in their catchments showed permanent flow; and second, the lowest variation in discharge (measured as CV, Table IV) was observed at Forest 2, which exhibited 


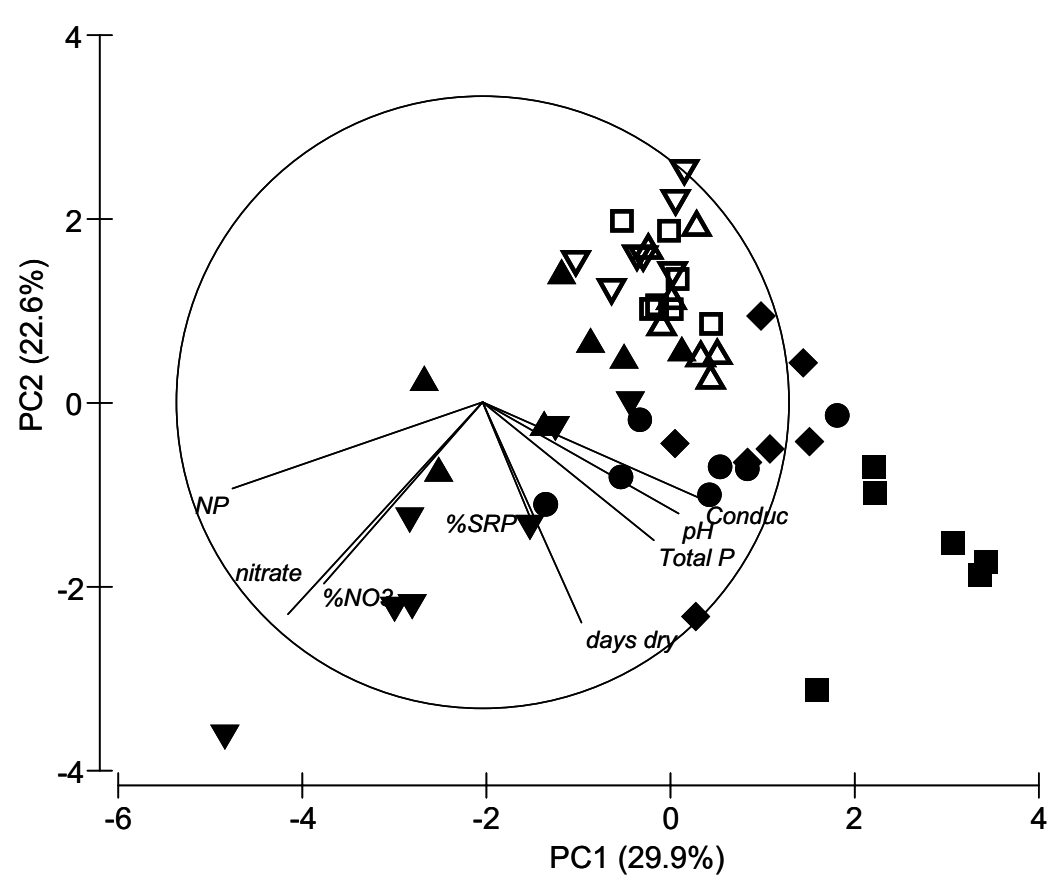

\begin{tabular}{|l|}
\hline \multicolumn{1}{|c|}{ stream } \\
Ocotal II \\
Santa Anita \\
Vista Hermosa 1 \\
Vista Hermosa 2 \\
$\Delta$ Forest 1 \\
$\square$ Forest 2 \\
$\nabla$ Forest 3 \\
$\nabla$ San Nicolas \\
\hline
\end{tabular}

\section{Figure 4}

Principal Component Analyses (PCA) based on stream variables measured during the wet season at the study sites. Variables responsible for the ordination are shown as vectors $(>30 \%)$. (nitrate, nitrate concentration; $p N O 3$, percent of nitrate in total N; NP, atomic NP ratio; total $P$, concentration of total $P$; pSRP, percent of SRP in total P; Conduc, specific conductance; Days dry, number of days the streams remained with no flow). Circle indicates maximum possible coefficient value for a given vector.

a catchment entirely covered by forest and did not experience water withdrawal from the channel.

The study intermittent streams had less than $60 \%$ of forest cover in their catchments, in addition to cultivated, pasture or urban areas. Although Ocotal II did not cease flowing during the dry season, the flow was reduced markedly (Figure 2). In the Huitepec, current agriculture and grassland areas probably were covered in the past by oak, oak-pine and tropical montane cloud forest (González-Espinosa et al., 1991; Ramírez-Marcial et al., 1998). There is evidence that the removal of cloud forest and its conversion into pastureland can lead to lower water in the soil, which influences baseflow (Ataroff and Rada, 2000). This change in land cover likely decreased the infiltration of water into the soil, resulting in reduced or no flow in streams during the dry season (Bruijnzeel, 2004). Based on simulations, Mulligan et al. (2010) concluded that impacts of tropical montane cloud forest removal on runoff increased markedly when forested areas in the catchment were reduced below $60 \%$, which is also the highest proportion of forest observed in the study intermittent streams. In addition, conversion into cropland and urban land also increases the demand of water for irrigation and domestic use which explains the placement of weirs in streams and water abstraction. The stream draining the largest study catchment, Vista Hermosa 2, experienced drought for the longest period. This stream had the highest proportion of urban land and stream water is stored in tanks in the upper part of the catchment. In addition, a carbonated beverage factory located at the base of the mountain extracts large amounts of groundwater (García-García, 2005), which probably lowers the water table and contributes to diminish stream flow during the dry season. These results suggest that under natural conditions, streams draining the Huitepec probably had permanent flow and changes in land use and water appropriation could be producing the flow intermittency observed at the more disturbed catchments.

The results of PCA and CAP analyses (Figures 4 and 5) suggest that disturbed catchments departed from the forest sites in the magnitude and temporal variability of physicochemical 


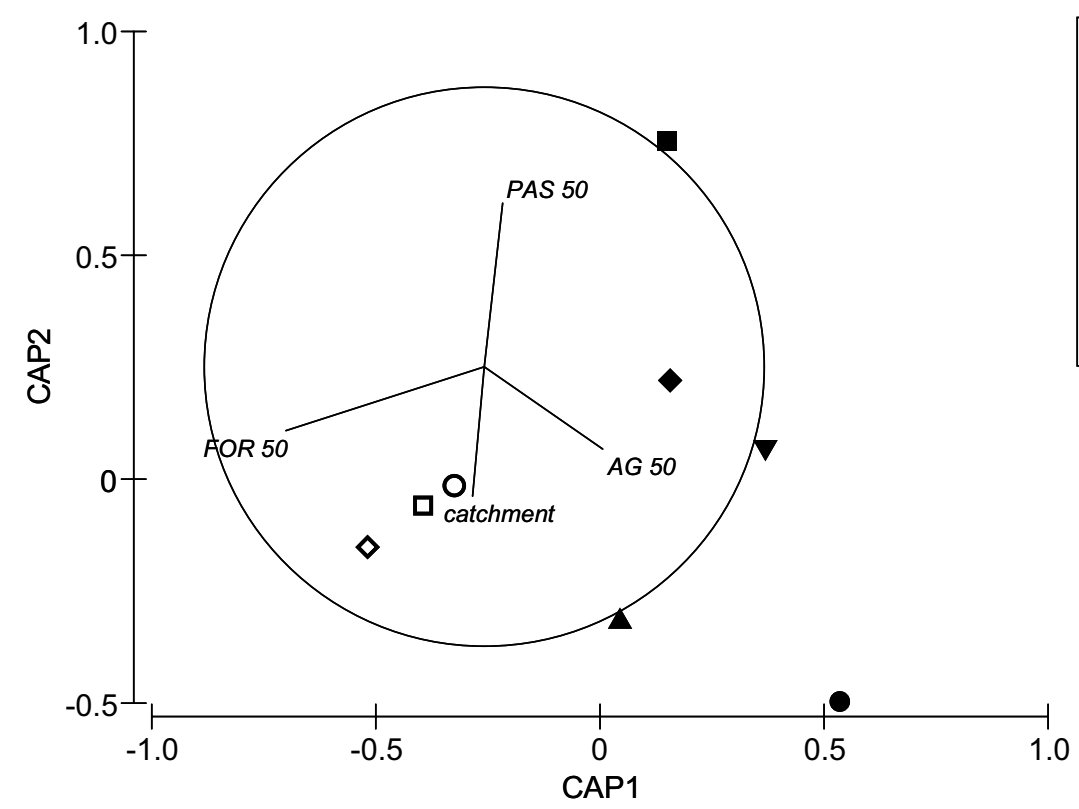

\begin{tabular}{|l|}
\hline \multicolumn{1}{|c|}{ stream } \\
$\boldsymbol{\Delta}$ Ocotal II \\
Santa Anita \\
Vista Hermosa 1 \\
Vista Hermosa 2 \\
O Forest 1 \\
$\square$ Forest 2 \\
$\checkmark$ Forest 3 \\
- San Nicolas \\
\hline
\end{tabular}

\section{Figure 5}

Canonical Analysis of Principal Coordinates (CAP) of centroids of streams calculated across sampling dates. Predictor variables (land use) best correlated (>40\%) with the constrained ordination of stream's centroids are shown as vectors. Variables correlated PAS $50=$ percentage of pasture at the $50 \mathrm{~m}$ buffer strip; AG 50 = percentage of agriculture at the $50 \mathrm{~m}$ buffer strip; FOR 50 = percentage of forest at the $50 \mathrm{~m}$ buffer strip; catchment = catchment area. Circle indicates maximum possible coefficient value for a given vector.

variables and nutrient levels. Dispersion, as a measurement of temporal variability, was lower at the forest catchments than at the rest of the sites (Table VI), which probably is related to flow intermittency, and greater variation in solute inputs from disturbed landscapes (Poor and Mc Donnell, 2007; Gómez et al., 2009; Bernal et al., 2012). Differences in pH, alkalinity and conductance values can be related, in part, to human disturbance but also geology can be affecting these variables. At Vista Hermosa 1, where highest $\mathrm{pH}$ and conductance values were recorded, occasional measurements at seepage areas (June 2008: pH, 7.5 and Specific conductance, $106 \mu \mathrm{S} \cdot \mathrm{cm}^{-1}$ ) located upstream from the regular sampling site (June 2008: $\mathrm{pH}$ 8.35, Specific conductance $449 \mu \mathrm{S} \cdot \mathrm{cm}^{-1}$ ) indicated a marked downstream increase in $\mathrm{pH}$ and conductance, suggesting the influence of human disturbances such as runoff from agricultural fields or domestic waste water disposal. However, other disturbed sites such as San Nicolás and Ocotal II did not show high values of these variables, indicating that other factors could also be affecting physicochemical variables. Differences in lithology between the southern part of the mountain, where volcanic brecchias occur, and the northern part, dominated by Dacite-Andesite rocks, combined with the presence of the limestone layer at the base of the volcano (Espíritu, 1998) could influence groundwater chemistry and be related to differences in $\mathrm{pH}$, conductivity and alkalinity among study sites, which were observed consistently at each sampling date. Thus, $\mathrm{pH}$, alkalinity and conductivity differences among sites probably are the result of both anthropogenic and natural influences.

Regarding nutrients, sites with more disturbed catchments exhibited increases in nitrogen and phosphorus concentrations, NP ratios and the proportions of nitrate or SRP. Nitrate values at the forest sites were lower than in rivers draining catchments covered by tropical cloud forest in central Mexico (Ramos-Escobedo and Vázquez, 2001; Martínez et al., 2009). However, concentrations were higher than values reported for streams in the Luquillo Experimental Forest, Puerto Rico, where Tabonuco (Dacryodes excelsa) and Colorado (Cyrilla racemiflora) forest types dominate (McDowell and Asbury, 1994) and in evergreen and rain forest areas in Costa Rica (Newbold et al., 1995). Values were similar to nitrate concentrations in streams 
draining mountain catchments covered by evergreen seasonal forest in northern Venezuela (Castillo, 2010) and in catchments in Ecuador where cloud forest is the dominant vegetation (Bücker et al., 2011). At some sites like San Nicolás and Vista Hermosa 1, nitrate and phosphorus concentrations were severalfold higher than at the rest of the streams. At San Nicolás, concentrations and proportion of nitrate of total nitrogen were similar to areas under intensive agriculture in North America (Omernik, 1977; Castillo et al., 2000; Royer et al., 2004). At most sites, except Vista Hermosa 1, phosphorus concentrations were similar to values reported by Ramos-Escobedo and Vázquez (2001) for streams draining cloud forest areas in Los Tuxtlas, Mexico, and within the range of values reported by Pringle et al. (1993) for streams draining volcanic areas in Costa Rica.

Increase in nutrient concentration at the disturbed sites in comparison to the forest sites, probably indicated the influence of intensive agriculture and the use of synthetic fertilizers. The correlation of stream variables with land use in the riparian zone as indicated by the CAP analysis (Figure 5) probably is related to the influence of riparian vegetation on water chemistry, particularly on nutrient loading (Novak et al., 2002; Mayer et al., 2005). Lack of correlation with land use at the catchment scale for categories known for their influence on nutrient levels such as cropland (Johnson et al., 1997; Dodds and Oakes, 2006) probably reflected the diversity of agricultural practices among the study catchments and the variability in the impacts that these land uses are causing on the Huitepec streams. For example, study catchments with higher proportion of cropland in their catchments (Ocotal II, Santa Anita, Vista Hermosa 1 and San Nicolás) exhibited large variation in nitrogen and phosphorus levels. The presence of conventional agriculture at San Nicolás, the application of synthetic fertilizers and the proximity of agriculture fields to the stream channel probably explains the high $\mathrm{N}$ concentrations at this site. In Vista Hermosa 1, increased P concentrations can be explained by the application of poultry manure, which has a high $\mathrm{P}$ content, as fertilizer in a relatively large organic farm (Hill and Cade-Menun, 2009; Kaiser et al., 2009). However, other sites such as Santa Anita and Ocotall II which also show a high proportion of cropland in their catchments did not show increases in nitrate or phosphorus concentrations as high as in San Nicolás or Vista Hermosa 1, respectively. At Santa Anita and Ocotal II, the use of compost and the higher proportion of forest in the riparian zone, probably are reducing the impacts of agriculture on nutrient loading. However, additional information on agricultural practices such as type and amount of fertilizer applied, type of crop and tillage, and nutrient concentrations in riparian and catchment soils would be helpful to obtain a more precise assessment of the effects of the different agricultural practices on streams.

Flow alteration and nutrient enrichment can affect habitat availability in headwater streams and impact the functioning of ecosystems downstream. Flow intermittency can reduce the availability of headwaters as refuge for aquatic organisms, considering the heavy pollution of downstream reaches due to urban growth of San Cristóbal de Las Casas (VelazquezVelázquez and Schmitter-Soto, 2004; Meyer et al., 2007). Alteration of water quality and flow of headwater streams can also affect the supply of clean water to alpine wetlands located in the Valley of the Jovel, some of which are included in the Ramsar List of Wetlands of International Importance (La Kisst, No. 1787 and María Eugenia, No. 2045) and are the habitat of the endangered endemic fish species, Profundulus hildebrandi (Velazquez-Velázquez and Schmitter-Soto, 2004). In addition, the observed alteration of flow and water quality can affect the supply of water for human consumption considering the importance of the Huitepec as water source for local communities (Arriaga et al., 2000) and the location of hydroelectric dams in the river network. The observed impacts of land use changes probably are also occurring in other areas of the Valley of Jovel and the Highlands of Chiapas, where high rates of forest conversion into agriculture and urban lands have been reported (Cayuela et al., 2006b; Figueroa-Jáuregui et al., 2011), and suggest that minimally disturbed headwater streams are disappearing from the region.

Considering the impacts that land use changes are having on the streams of Huitepec and the potential implications for the downstream ecosystems, it is necessary to adopt some practices to reduce alteration of hydrology and nutrient levels. Conservation of remaining forest 
areas in the Huitepec is important to prevent further changes in the seasonal distribution of flows and its effects on downstream ecosystems. However, it is not sufficient to protect the terrestrial ecosystems to protect the streams (Pringle, 2001; Abell et al., 2007). Water abstraction can represent a threat to the study streams considering the current and future demand for water in the Huitepec. Although the natural protected area Alcanfores-Huitepec and the Huitepec Ecological Reserve already are preserving part of the remaining forested areas, it is necessary to promote forest conservation incentives outside the protected areas. Conservation of the remaining forest fragments and the traditional agricultural systems can help to maintain the high quality landscape matrix and reduce the effects of intensive agriculture observed in this study. Traditional and organic land use practices in the study area probably have less impact on nitrogen loading than conventional agriculture, as indicated by our results, but it is not clear whether water quality and riparian vegetation conservation are promoted by these practices. Managing the type and amount of fertilizer application and enhancing the conservation and restoration of the riparian vegetation probably will reduce nutrient loading into the streams. The conservation of stream ecosystems in the Huitepec Mountain requires an approach that integrates the management of both terrestrial and aquatic systems.

\section{ACKNOWLEDGEMENTS}

We are grateful to Catalina Meza, Pedro Ramírez and Conrado Trujillo for field assistance. PRONATURA-CHIAPAS provided helpful information about the Huitepec Ecological Reserve. We thank Agathe Valory for the French translation of the abstract. This research was conducted with financial support from the Diversity in Agricultural Systems Group from El Colegio de la Frontera Sur.

\section{REFERENCES}

Abell R., Allan J.D. and Lehner B., 2007. Unlocking the potential of protected areas for freshwaters. Biol. Conserv., 134, 48-63.

Albarrán J.J., Tenorio F.G. and Valencia-Islas J.J., 2003. El vulcanismo cuaternario chiapaneco y su relación con el marco tectónico del basamento cristalino de las cuencas del sureste. Actas del Instituto Nacional de Geoquímica, 9, 134-138.

Alexander R.B., Boyer E.W., Smith R.A., Schwartz G.E. and Moore R.B., 2007. The role of headwater streams in downstream water quality. J. Am. Water. Resour. Assoc., 43, 41-59.

Anderson M.J. and Willis T.J., 2003. Canonical analysis of principal coordinates: a useful method of constrained ordination for ecology. Ecology, 84, 511-525.

A.P.H.A., 1995. Standard methods for the examination of water and wastewater, 21th edn. Washington, D.C., A.P.H.A.

Arriaga L., Espinoza J.M., Aguilar C., Martínez E., Gómez L. and Loa, E., 2000. Regiones terrestres prioritarias de México. México, DF: Comisión Nacional para el Conocimiento y uso de la Biodiversidad.

Ataroff M. and Rada F., 2000. Deforestation impact on water dynamics in a Venezuelan Andean cloud forest. Ambio, 29, 440-444.

Benda L., Hassan M.A., Church M. and May C.L., 2005. Geomorphology of steepland headwaters, the transition from hillslopes to channels. J. Am. Water. Resour. Assoc., 41, 835-851.

Bernal S., von Schiller D., Sabater F., Martí E., 2012. Hydrological extremes modulate nutrient dynamics in Mediterranean climate streams across different spatial scales. Hydrobiologia, DOI: $10.1007 / \mathrm{s} 10750-012-1246-2$.

Binckley C.A., Wipfli M.S, Medhurst R.B., Polivka K., Hessburg P., Salter R.B. and Kill J.Y., 2010. Ecoregion and land-use influence invertebrate and detritus transport from headwater streams. Freshwater Biol., 55, 1205-1218.

Bruijnzeel L.A., 2004. Hydrological functions of tropical forests: not seeing the soil for the trees? Agr. Ecosyst. Environ., 104,185-228. 
Bücker A., Crespo P., Frede H.G., and Breuer L., 2011. Solute behaviour and export rates in neotropical montane catchments under different land-uses. J. Trop. Ecol., 27, 305-317.

Caballero L., Macías J.L., García-Palomo.A., Saucedo G.R., Borsellu L., Sarocchi D. and Sánchez J.M., 2006. The September 8-9, 1998 rain-triggered flood events at Motozintla, Chiapas, Mexico. Nat. Hazards, 39, 103-126.

Castillo M.M., Allan J.D. and Brunzell S., 2000. Nutrient concentrations and discharges in a midwestern agricultural catchment. J. Environ. Qual., 29, 1142-1151.

Cayuela L., Golicher J.D., Salas Rey J., and Rey Benayas J.M., 2006a. The extent, distribution, and fragmentation of vanishing cloud forest in the highlands of Chiapas, Mexico. Biotropica, 38, 544-554.

Cayuela L., Rey-Benayas J.M. and Echeverría C., 2006b. Clearance and fragmentation of tropical montane forests in the Highlands of Chiapas, Mexico (1975-2000). Forest Ecol. Manag., 226, 208-218.

Clapcott J.E. and Bermuta L.A., 2010. Forest clearance increases metabolism and organic matter processes in small headwater streams. J. N. Am. Benthol. Soc., 29, 546-561.

Clarke K.R. and Ainsworth M., 1993. A method of linking multivariate community structure to environmental variables. Mar. Ecol. Prog. Ser., 92, 205-219.

Dodds W.K. and Oakes R.M., 2006. Controls on nutrients across a prairie stream watershed: land use and riparian cover effects. Environ. Manage., 37, 634-646.

Elmore A.J. and Kaushal S.J., 2008. Disappearing headwaters: patterns of stream burial due to urbanization. Front. Ecol. Environ., 6, 308-312.

Espíritu G., 1998. Evaluación de la disponibilidad de agua mediante análisis geográfico en la cuenca San Cristóbal, Chis. Master's Thesis, El Colegio de la Frontera Sur, San Cristóbal de las Casas, México.

Figueroa-Jáuregui M.L., Ibáñez-Castillo A., Arteaga-Ramírez R., Arellano-Monterrosas J.L. and Vázquez-Peña M., 2011. Cambio de uso de suelo en la cuenca de San Cristóbal de Las Casas, México. Agrociencia, 45, 531-544.

Freeman M.C., Pringle C.M. and Jackson C.R., 2007. Hydrologic connectivity and the contribution of stream headwaters to ecological integrity at regional scales. J. Am. Water. Resour. Assoc., 43, 5-14.

García-García A., 2005. La gestión del agua en la cuenca endorreica de San Cristóbal de Las Casas, Chiapas, México. Master's Thesis, Univesidad Autónoma de Chapingo, Chapingo, México.

Gómez R., García, V., Vidal-Abarca R., Suárez L., 2009. Effect of intermittency on N spatial variability in an arid Mediterranean stream. J. N. Am. Benthol. Soc., 28, 572-583.

Gomi T., Sidle R. and Richardson J.S., 2002. Understanding Processes and Downstream Linkages of Headwater Systems. BioScience, 52, 905-916.

González-Espinosa M., Quintana-Ascencio P.F., Ramírez-Marcial N., and Gaytán-Guzmán P., 1991. Secondary succession in disturbed Pinus-Quercus forests in the highlands of Chiapas, Mexico. J. Veg. Sci., 2, 351-360.

González-Espinosa M., Ramírez-Marcial N., Galindo-Jaimes L., Camacho-Cruz A., Golicher D., Cayuela L., and Rey-Benayas J.M., 2009. Tendencias y proyecciones del uso del suelo y la diversidad florística en Los Altos de Chiapas, México. Investigación Ambiental, 1, 40-53.

Hill J.E. and Cade-Menun B.J., 2009. Phosphorus-31 nuclear magnetic resonance spectroscopy transect study of Poultry operations on the Delmarva Peninsula. J. Environ. Qual., 38, 130-138.

Johnson L.B., Richards C., Host G.E. and Arthur J.W., 1997. Landscape influences on water chemistry in Midwestern stream ecosystems. Freshwater. Biol., 37, 193-208.

Kaiser D.E., Mallarino A.P., Haq M.U. and Allen B.L., 2009. Runoff phosphorus loss immediately after poultry manure application as influenced by the application rate and tillage. J. Environ. Qual., 38, 299-308.

Ledo A., Condes S., and Alberdi I., 2012. Forest biodiversity assessment in Peruvian Andean Montane cloud forest. J. Mt. Sci., 9, 372-384.

Lowe W.H. and Likens G.E., 2005. Moving headwater streams to the head of the class. Bioscience, 55, 196-197.

Martínez M.L., Pérez-Maqueo O., Vázquez G., Castillo-Campos G., García -Franco J.G., Mehltreter K.V., Equihua M.E. and Landgrave R., 2009. Effects of land use change on biodiversity and ecosystem services in tropical montane cloud forests of Mexico. Forest Ecol. Manag., 258, 1856-1863. 
Mayer P.M.S., Reynolds K. Jr., Canfield T.J. and McCutchen M.D., 2005. Riparian Buffer Width, Vegetative Cover, and Nitrogen Removal Effectiveness: A Review of Current Science and Regulations. EPA/600/R-05/118. National Risk Management Research Laboratory, Office of Research and Development, U.S. Environmental Protection Agency, Cincinnati.

McDowell W.H. and Asbury C.E., 1994. Export of carbon, nitrogen, and major ions from three tropical montane watersheds. Limnol. Oceanogr., 39, 1-125.

Meyer J.L. and Wallace J.B., 2001. Lost linkages and lotic ecology: rediscovering small streams. In: Press M.C., Huntly N.J. and Levin S. (eds.), Ecology: achievement and challenge, Blackwell Science, Oxford, 295-317.

Meyer J.L., Strayer D.L., Wallace J.B., Eggert S.L., Helfman G.S. and Leonard N.E., 2007. The contribution of Headwater Streams to Biodiversity in River Networks. J. Am. Water. Resour. Assoc., 43, 86-103.

Morales H., Ferguson B. and García-Barrios L., 2003. Agricultura: La cenicienta de la conservación en Mesoamérica. In: Harvey C. and Sáenz J. (eds.), Evaluación y Conservación de Biodiversidad en Paisajes Fragmentados de Mesoamérica, INBio, San José de Costa Rica, 47-73.

Morales H., Castillo M.M., Nigh R. and Valencia E. In press. Conservación del Huitepec: Mirando hacia afuera de la reserva. In: IDESMAC-CONABIO (eds.), La biodiversidad en Chiapas: estudio de estado, CONABIO, México, 298-299.

Mulligan M., 2010. Modelling the tropics-wide extent and distribution of cloud forest and cloud forest loss, with implications for conservation priority. In: Bruijnzeel L.A., Scatena F.N. and Hamilton L.S. (eds.), Tropical Montane Cloud Forests: Science for conservation and management, Cambridge University Press, Cambridge, 64-108.

Mulligan M., Rubiano J. and Rincón-Romero M., 2010. Hydrology and land-cover change in tropical montane environments: the impacts of pattern on process. In: Bruijnzeel L.A., Scatena F.N. and Hamilton L.S. (eds.), Tropical Montane Cloud Forests: Science for conservation and management, Cambridge University Press, Cambridge, 416-424.

Newbold J.D., Sweeney B.W., Jackson J.K. and Kaplan L.A., 1995. Concentrations and export of solutes from six mountain streams in northwestern Costa Rica. J. N. Am. Benthol. Soc., 14, 21-37.

Novak J.M., Hunt P.G., Stone K.C., Watts D.W., Johnson M.H., 2002. Riparian zone impact on phosphorus movement to a Coastal Plain black water stream. J. Soil Water. Conserv., 57, 127-133.

Ochoa-Gaona S., 2001. Traditional land-use systems and patterns of forest fragmentation in the Highlands of Chiapas, Mexico. Environ. Manage., 27, 571-586.

Ochoa-Gaona S. and González-Espinosa M., 2000. Land use and deforestation in the highlands of Chiapas, Mexico. Appl. Geogr., 20, pp. 17-42.

Omernik J.M., 1977. Non-point source-stream nutrient level relationships: a nationwide study, EPA600/3-77- 105, US Environmental Protection Agency, Corvallis, 33 p.

Peterson B. J., Wollheim W.M., Mulholland P.J., Webster J.R., Meyer J.L., Tank J.L., Marti E., Bowden W.B., Valett H.M., Hershey A.E., McDowell W.H., Dodds W.K., Hamilton S.K., Gregory S. and Morrall D.D., 2001. Control of nitrogen export from water sheds by headwater streams. Science, 292, 86-90.

Polis G.A., Anderson W.B. and Holt R.D., 1997. Toward an integration of landscape and food web ecology: the dynamics of spatially subsidized food webs. Annu. Rev. Ecol. Evol. S., 28, 289-316.

Ponce-Reyes R., Reynoso-Rosales V.H., Watson J.E.M., VanDerWal J., Fuller R.A., Pressey R.L., and Possingham H.P., 2012. Vulnerability of cloud forest reserves in Mexico to climate change. Nature Clim. Change, 2, 448-452.

Ponette- González, A., Weathers K.C., Curran L.M., 2010. Water inputs across a tropical montane landscape in Veracruz, Mexico: synergistic effects of land cover, rain and fog seasonality, and interannual precipitation variability. Glob. Change Biol.,16, 946-963.

Poor C.J. and McDonnell J.J., 2007. The effects of land use on stream nitrate dynamics. J. Hydrol., 332, $54-68$.

Pringle C.M., 2001. Hydrologic connectivity and the management of biological reserves: A global perspective. Ecol. Appl., 11, 981-998.

Pringle C.M., Rowe G.L., Triska F.J., Fernandez J.F. and West J., 1993. Landscape linkages between geothermal activity, solute composition and ecological response in streams draining Costa Rica's Atlantic Slope. Limnol. Oceanogr., 38, 753-774. 
Ramírez-Marcial N., Ochoa Gaona S., González M. and Quintana P., 1998. Análisis florístico y sucesional en la Estación Biológica Cerro Huitepec, Chiapas, México. Acta Bot. Mex., 44, 59-85.

Ramos-Escobedo M.G. and Vázquez G., 2001. Major ions, nutrients and primary productivity in volcanic neotropical streams draining rainforest and pasture catchments at Los Tuxtlas, Veracruz, Mexico. Hydrobiologia, 445, 67-76.

Reardon J., Foreman J.A. and Searcy R.L., 1966. New reactants for the colorimetric determination of ammonia. Clin. Chim. Acta, 14, 403-405.

Royer T.V., Tank J.L. and David M.B., 2004. Transport and Fate of Nitrate in Headwater Agricultural Streams in Illinois. J. Environ. Qual., 33, 1296-1304.

Sánchez M.D., Rosales-Mendez M. and Murgueitio E., 2003. Agroforestería pecuaria en América Latina. In: Sánchez M.D. y Rosales-Méndez M. (eds). Agroforestería para la Producción Animal en America Latina-II. FAO, Roma, 1-12.

Scatena F.N., Bruijnzeel L.A., Bubb P., Das, S., 2010. Setting the stage. In: Bruijnzeel L.A., Scatena F.N. and Hamilton L.S. (eds.), Tropical Montane Cloud Forests: Science for conservation and management, Cambridge University Press, Cambridge, 38-63.

Siddle R.C., Tsuboyama Y., Noguchi S., Hosoda I., Fujieda M. and Shimizu T., 2000. Stormflow generation in steepforested headwaters: a linked hydrogeomorphic paradigm. Hydrol. Process., 14, 369-385.

Toledo-Aceves T., Meave J.A., González-Espinosa M., Ramírez-Marcial N., 2011. Tropical montane cloud forests: Current threats and opportunities for their conservation and sustainable management in Mexico. J. Environ. Manage., 92, 974-981.

Vargas-Rodriguez Y.L., Platt W.J., Vazquez-Garcia, J.A., and Boquin G., 2010. Selecting Relict Montane Cloud Forests for Conservation Priorities: The Case of Western Mexico. Nat. Areas J., 30, 156-173.

Velázquez-Velázquez E. and Schmitter-Soto J.J. 2004. Conservation status of the San Cristóbal pupfish Profundulus hildebrandi Miller (Teleostei: Profundulidae) in the face of urban growth in Chiapas, Mexico. Aquat. Conserv. Mar. Freshw. Ecosyst., 14, 201-209.

Wilson J. and Will T., 1997. The current status of the Pink-headed Warbler Ergaticus versicolor in Chiapas, Mexico. Cotinga, 8, 34-38.

Winter T.C., 2007. The role of ground water in generating streamflow in headwater areas and in maintaining base flow. J. Am. Water. Resour. Assoc., 43, 15-25.

Wipfli, M.S., Richardson J.S. and Naiman R.J., 2007. Ecological linkages between headwaters and downstream ecosystems: transport of organic matter, invertebrates, and wood down headwater channels. J. Am. Water. Resour. Assoc., 43, 72-85.

Woods R., Sivapala M. and Duncan M., 1995. Investigating the representative elementary area concept: An approach based on field data. Hydrol. Process., 9, 291-312. 